\title{
Stabilized Organic Matter Quantities May Strongly Affect the Mobility of Glyphosate into Soil
}

\author{
Paulo Roberto Dores-Silva ${ }^{1}$, Fernanda Benetti ${ }^{1}$, Bruno Molero Silva ${ }^{2}$, Maria Diva Landgraf ${ }^{1}$ \\ \& Maria Olímpia Oliveira Rezende ${ }^{1}$ \\ ${ }^{1}$ Institute of Chemistry of São Carlos, University of São Paulo, São Carlos, SP, Brazil \\ ${ }^{2}$ Universidade Anchieta, Jundiaí, SP, Brazil \\ Correspondence: Maria Olímpia Oliveira Rezende, Institute of Chemistry of São Carlos, University of São Paulo, \\ São Carlos, SP, Brazil. Tel: 55-16-3373-9959. E-mail: mrezende@iqsc.usp.br
}

Received: April 1, 2016

doi:10.5539/jas.v8n9p135
Accepted: July 2, 2016

Online Published: August 15, 2016

URL: http://dx.doi.org/10.5539/jas.v8n9p135

\begin{abstract}
Glyphosate [N-(phosphonomethyl) glycine] is an enzyme inhibiting herbicide, which is widely used in the world. Here, we investigate the glyphosate adsorption potential in tropical soils with $\mathrm{pH}$ close to 5 . The herbicide was determined via HPLC with detection by UV-Vis. Our results suggest that glyphosate interacts especially with the stabilized organic matter. Thus, even with large amounts of soil organic matter, the soils may not be as effective in the adsorption of the herbicide if they do not also possess high percentage of humic substances. These data are worth far as it allows us to speculate on glyphosate interaction mechanism with the humic substances in slightly acid medium, in addition, also enable us to propose the use of that fraction of the organic matter to immobilize part of the herbicide in the soil and inhibiting its leaching into water bodies.
\end{abstract}

Keywords: glyphosate, adsorption, soil organic matter, humic substances

\section{Introduction}

Among the several methods typically used to control the proliferation of weeds in crops, chemical methods are the most used. Concerning the methods to control weeds, the use of herbicides is quick, and easy to apply in crops (Green, 2014). The previous recognition of the predominant invasive plant is a basic condition for the proper choice of the product that will result in weed control of fruitful manner. On the other hand, the use of herbicides involves high losses of economic, social and environmental nature (Kraehmer et al., 2014). When used incorrectly, or for long periods, herbicides may affect terrestrial and aquatic environments. Herbicides may also be responsible for high levels of contamination and/or intoxication levels recorded between producers and rural workers, as well as lead to contamination of food (Annett et al., 2014).

The soil organic matter content is an important factor in the persistence of the herbicides in soil. The carbon percentage can vary from less than $1 \%$ up to $50 \%$ (Wang et al., 2010). The organic matter content in agricultural soils can vary from 1 to $15 \%$, however this value strongly depends on the type and on the soil management. The acidity of the soil is also crucial, since the concentration of ions can influence the breakdown of the molecules of the pesticides into the soil in many ways. It can affect the stability of the clay material, ion exchange capacity, or the rates at which the chemical and bacterial decomposition occur. However, there is little evidence that the acidity influence the persistence of herbicides in soil (Beckie, 2011).

Glyphosate [N-(phosphonomethyl) glycine], whose molecular formula is $\mathrm{C}_{3} \mathrm{H}_{8} \mathrm{NO}_{5} \mathrm{P}$, works inhibiting the 5-enolpyruvylshikimate-3-phosphate synthase that is responsible for production of aromatic amino acids (Rubin, Gaines, \& Jensen, 1984). It was synthetized in 1970 by a group of scientists from Monsanto Company (USA). The glyphosate molecule consists of carbonyl functional groups, amine and phosphonate which result in different ionic charges on the glyphosate molecule depending on the $\mathrm{pH}$ (Kylin, 2013), this fact is extremely important when evaluating the glyphosate mobility in soil.

It has been showed that glyphosate is strongly adsorbed by inorganic soil components especially aluminum and iron oxides, and the phosphate group have being involved in this interaction (Toni et al., 2006; Tonini et al., 2010). The inactivation of glyphosate in soils can last for days or even months depending on soil characteristics 
(Duke \& Powles, 2007; Toni et al., 2006; Albers et al., 2009). The extent of glyphosate sorption in soils depends on different parameters, such as soil constituents and pedoclimatic conditions.

Despite its affinity for soil mineral phases (Ghafoor et al., 2013), glyphosate has been proved to bind also to soil organic constituents, such as humic substances (Albers et al., 2009). Humic substances are constituted of relatively low molecular mass moieties bound together mainly by $\mathrm{H}$ bonding and hydrophobic links (Moraes \& Rezende, 2004; Piccolo et al., 1996). Their structure is sensitive to ambient conditions such as pH, ionic strength, and also to their own concentration (Trevisan et al., 2010). At high concentration of salts and/or humic substances themselves, they exhibit more compact sphero-colloidal structures, also linked with a decrease in intramolecular repulsive forces. Under these conditions, a decrease in the surface area and the disappearance of certain structural microporous are observed (Alvarez-Puebla \& Garrido, 2005), diminishing their binding potential for pollutants.

Studies investigating the mobility of glyphosate in soil also indicate that the potential for leaching appears to be limited, although there are studies showing that leaching may occur (Jodeh et al., 2014). A leaching mechanism for strongly sorbed chemicals that has received increasing attention during recent years is what is referred to as colloid-facilitated transport. Through this mode of transport, in combination with preferential flow, strongly sorbed compounds can potentially migrate long distances in soil. This can explain why glyphosate is frequently found in surface waters and sometimes even in groundwater, although there is still no strong evidence for this hypothesis (Jodeh et al., 2014).

In this paper, we investigate the glyphosate adsorption potential in tropical soils with $\mathrm{pH}$ close to 5 . To determine the herbicide we have developed an efficient method via HPLC with detection by UV-Vis dispensing the step of extraction and clean-up, capable to determine glyphosate in environmental samples of water, soil and sediment (Silva et al., 2015). Our results suggest that glyphosate interacts especially with the stabilized organic matter. Thus, even with large amounts of soil organic matter, the soils may not be as effective in the adsorption of the herbicide if they do not also possess high percentage of humic substances. These data are worth far as it allows us to speculate on glyphosate interaction mechanism with the humic substances in slightly acid medium, in addition, also enable us to propose the use of that fraction of the organic matter to immobilize part of the herbicide in the soil and inhibiting its leaching into water bodies.

\section{Materials and Methods}

\subsection{Soil Preparation and Characterization}

The study was conducted in the upper basin of the Jacaré-Guaçu river, located in the central-eastern region of São Paulo state, with a length of approximately $1,100 \mathrm{~km}^{2}$, defined by the following geographical coordinates: $21^{\circ} 57^{\prime} 30^{\prime \prime}$ and $22^{\circ} 22^{\prime} 30^{\prime \prime}$ south latitude and $47^{\circ} 42^{\prime} 30^{\prime \prime}$ and $48^{\circ} 05^{\prime} 30^{\prime \prime}$ west longitude. For the adsorption experiments, the test was performed using seven agricultural soil samples with different levels of organic matter. The soils were determined for glyphosate by the established method to check that the evaluated soils were free of glyphosate.

The chemical characterization of soil samples were based on the following attributes: $\mathrm{pH}$ in $0.01 \mathrm{~mol} \mathrm{~L}^{-1} \mathrm{CaCl}_{2}$; organic matter content (burnt for 4 hours at $560^{\circ} \mathrm{C}$ ); clay content was determined according to NBR 7181, using decantation with sodium hexametavanadate (ABNT, 1986, 1984), and humic substances content by using the method proposed by the International Humic Substances Society (IHSS) (Sparks et al., 1996).

\subsection{Development of Methodology for Determination of Glyphosate in Soil}

A Partisil 10 SAX anion exchange column $(250 \times 4.6 \mathrm{~mm})$ was used for the chromatographic separation. The column temperature was controlled at $25{ }^{\circ} \mathrm{C}$ during analysis. The mobile phase was a $0.01 \mathrm{~mol} \mathrm{~L}^{-1}$ phosphate buffer (pH 2.0 adjusted with phosphoric acid). Flow rate was $1.0 \mathrm{~mL} \mathrm{~min}^{-1}$ (isocratic mode), the injection volume was $20 \mu \mathrm{L}$ and the total analysis time was $10 \mathrm{~min}$. The chromatographic conditions were chosen in terms of peak shape, column efficiency, chromatographic analysis time, selectivity and resolution. The wavelength used was $195 \mathrm{~nm}$

Glyphosate stock solutions $\left(100 \mathrm{mg} \mathrm{L}^{-1}\right)$ were prepared in ultra-purified water. Working standard solutions were prepared by dilution $\left(50,75,150,300\right.$ and $\left.500 \mu \mathrm{g} \mathrm{L}^{-1}\right)$ for linearity study. These solutions were stored at $4{ }^{\circ} \mathrm{C}$.

Method validation was based on AOAC guideline (Association of Official Analytical Chemists, 2002).

Precision (repeatability, in terms of $\%$ RSD) and accuracy (percentage recoveries) were estimated by recovery experiments in soil, at three fortification levels each $\left(1.0,2.0\right.$ and $\left.3.0 \mathrm{mg} \mathrm{kg}^{-1}\right)$, and analyzed in triplicate. Recoveries between $70 \%-120 \%$, with RSD lower than $20 \%$, were considered satisfactory. 


\subsection{Sorption Studies}

The sorption tests were performed by placing $1.0 \mathrm{~g}$ of each sample in $150.0 \mathrm{~mL}$ Erlenmeyer flasks plus $10.0 \mathrm{~mL}$ of glyphosate solutions at $2,000 \mu \mathrm{g} \mathrm{L}{ }^{-1}$ concentrations taking an aqueous solution of $\mathrm{CaCl}_{2} 0.01 \mathrm{~mol} \mathrm{~L}^{-1}$ as an electrolyte-support. Those samples were subjected to orbital shaking in a mechanical shaker by 12 hours at room temperature. Then, the samples were centrifuged for $15 \mathrm{~min}$ at $3000 \mathrm{rpm}$. The supernatants were carefully removed, filtered through $0.45 \mu \mathrm{m}$ filter and then determined by HPLC UV-Vis. The adsorption was calculated by subtraction between the initial concentration and the concentration found in equilibrium liquid fraction determined after 12 hours (Silva et al., 2015).

\subsection{Statistic Treatment}

All determinations were performed in five replicates, determining the arithmetic mean and then the standard deviation. The data were analyzed using Student's t-test and differences were considered significant at $\mathrm{P}<0.05$.

All data were obtained according the good laboratory practices.

\section{Results and Discussion}

\subsection{Determination of Glyphosate in Soil Samples by HPLC UV-Vis}

The determination of glyphosate in the studied samples was performed according Silva, Benetti, and Rezende (2015) with adaptations. Figure 1 shows a typical chromatogram for a real soil sample. As inset, Figure 1 shows a calibration curve used for the determination of glyphosate in the samples of interest. All soil samples used for the study of adsorption have previously been tested using the above-mentioned method to determine the analyte of interest.

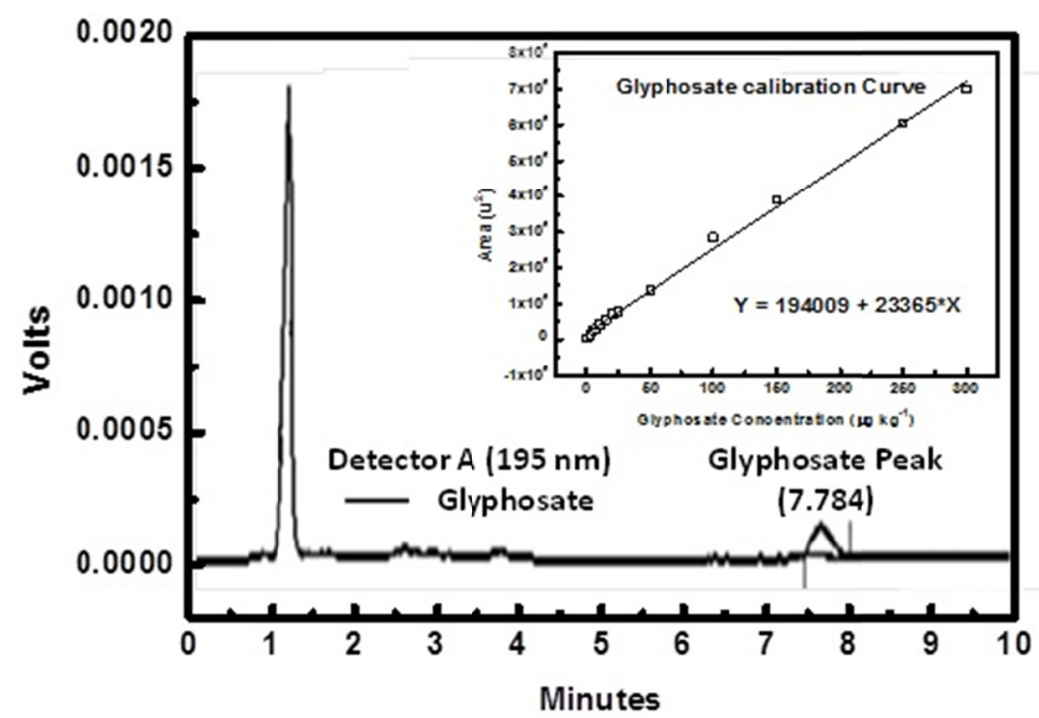

Figure 1. Chromatogram of glyphosate in soil in a concentration of $1,000 \mu \mathrm{g} \mathrm{kg}^{-1}$. It is shown a typical chromatogram for a natural soil sample. As inset, a calibration curve used for the determination of glyphosate in the samples of interest is shown (for more details see the text)

\subsection{Sampling and Characterization of Soils}

The soil used in this study comprised a type of soil known as Oxisoil differing primarily in the amounts of organic matter. Seven collected samples from different locations were characterized according to the organic matter content, clay content and $\mathrm{pH}$. Figure 2 shows the results obtained for the organic matter content of the samples. A variation in the organic matter content from 1 up to $11 \%$ can be observed. As inset, Figure 2 shows the variation in clay content, which was from 7.5 up to $9.0 \%$. It should be noted that the particle size analysis revealed that the sand fraction was predominant in the seven soil samples studied (data not shown), so the samples were considered sandy with a similar amount of clays, with the major difference the organic matter content. Thus, the real evaluated matrices have a huge potential for the study of the influence of organic matter on the adsorption of glyphosate. 


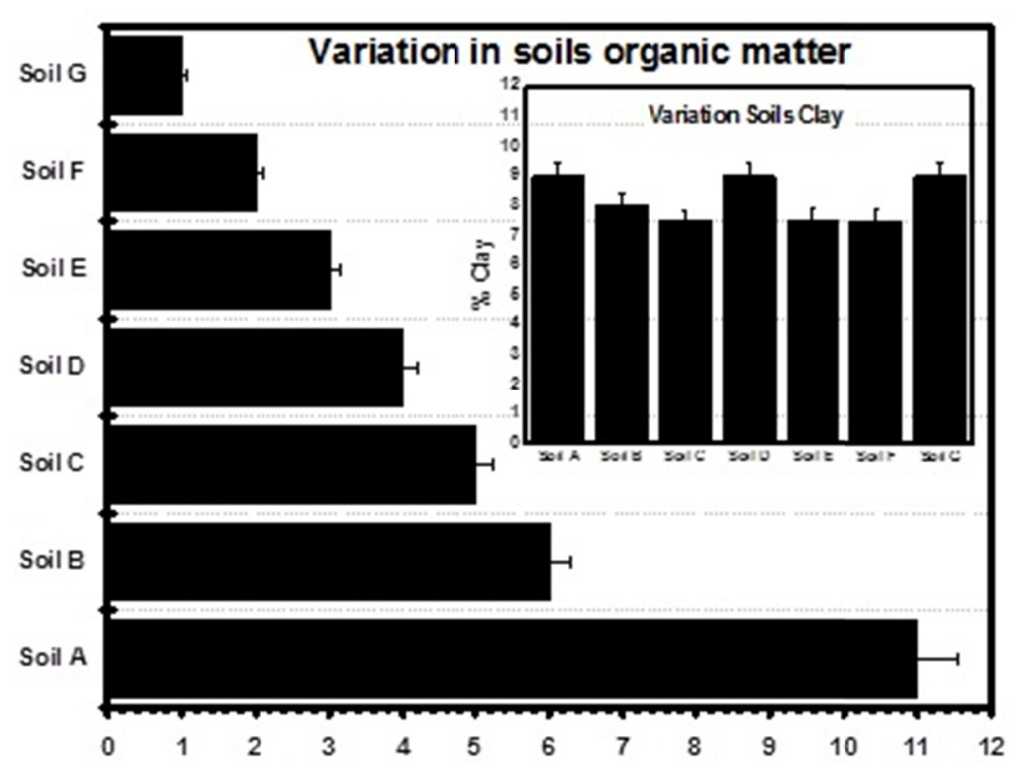

Figure 2. Organic matter content of the soil samples studied. The figure shows the results obtained for the organic matter content of the samples. A variation in the organic matter content from 1 up to $11 \%$ can be observed. As inset, the variation in clay content, which was from 7.5 up to $9.0 \%$ (for more details see the text)

Figure 3 shows the variation of $\mathrm{pH}$ for the different samples. Interestingly, this variation makes a very close value of 5 for all samples, suggesting strongly that the means to interact with the glyphosate was slightly acidic. It should be noted this buffering effect in the fraction known as solution of the soil, so the soil can withstand rapid changes in $\mathrm{pH}$. Thus, the means of interaction among herbicide and organic fraction and the inorganic fraction is buffered to a $\mathrm{pH}$ close to 5 . It is also worth to emphasize that due to the high microbial activity, most tropical soils have slightly acidic reaction media, allowing speculate that the interaction mechanisms for glyphosate in tropical soils with similar chemical composition to those described herein, should be closely comparable, which allows data to be extrapolated.

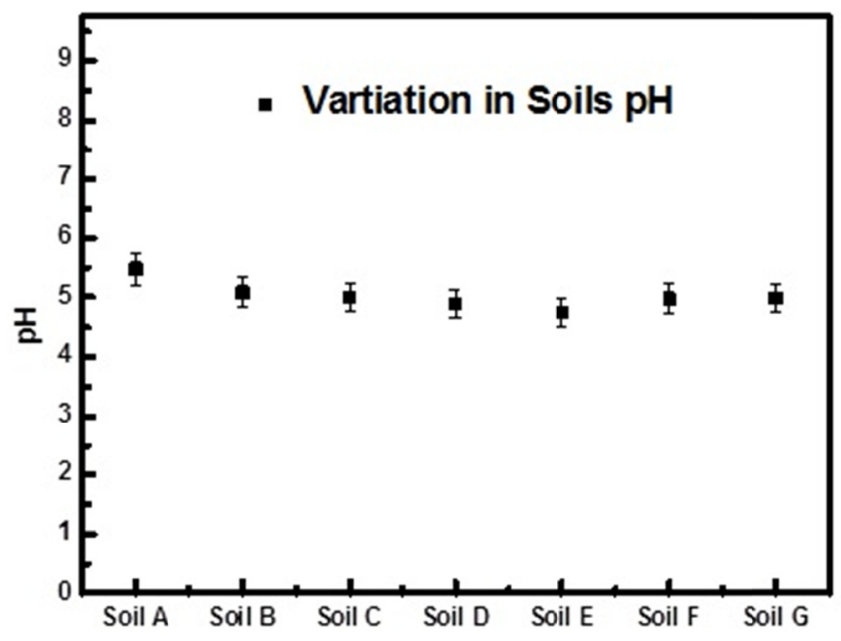

Figure 3. Variation of acidity in the soil samples

This variation makes a very close value of 5 for all samples, suggesting strongly that the means to interact with the glyphosate was slightly acidic. It should be noted this buffering effect in the fraction known as solution of the soil, so the soil can withstand rapid changes in $\mathrm{pH}$. 
Glyphosate has four ionizable groups with $\mathrm{pKa}$ namely: $\mathrm{pK}_{1}=0.80 ; \mathrm{pK}_{2}=2.23 ; \mathrm{pK}_{3}=5.46$ and $\mathrm{pK}_{4}=10.14$. Thus, at the $\mathrm{pH}$ of the samples at least two groups were deprotonated, leading the glyphosate molecule a negative character in phosphonic grouping. This fact is important because it allows speculate glyphosate interaction mechanisms with different functional groups of organic matter or clays.

\subsection{The Humic Fraction of the Organic Matter is Largely Responsible for the Adsorption of Glyphosate in Soils}

Table 1 shows the results for the adsorption of glyphosate in the evaluated samples in order of increasing organic matter. Interestingly, assessing the Table 1 the adsorbent capacity of the samples apparently does not seem to be related to the content of organic matter present in them, this fact is at least unusual, because in the literature it is well established that the presence of organic matter causes an increase in the adsorption of the herbicide in question.

Table 1. The adsorption of glyphosate in the evaluated samples in order of increasing organic matter (O.M.)

\begin{tabular}{lll}
\hline Sample & \% O.M. & Adsorption $\left(\mu \mathrm{g} \mathrm{g}^{-1}\right)^{*} 10^{-2}$ \\
\hline Soil A & $11.0(0.6)$ & $416(21)$ \\
Soil B & $6.0(0.3)$ & $297(15)$ \\
Soil C & $5.0(0.2)$ & $98(5)$ \\
Soil D & $4.0(0.2)$ & $361(18)$ \\
Soil E & $3.0(0.1)$ & $48(3)$ \\
Soil F & $2.0(0.1)$ & $237(12)$ \\
Soil G & $1.0(0.1)$ & $14(2)$ \\
\hline
\end{tabular}

Seeking to better understanding the role of organic matter on adsorption of glyphosate in the soil samples evaluated, we determined the amount mass of humic substances present in each sample (Table 2). Humic substances of organic matter represent the fraction more stabilized. It is known that the humic fraction of different soils has different constitutions, since several factors contribute to its formation such as source material, kind of microorganisms during the humification process, weather conditions etc. Thus, there is not a straight relationship between amount of organic matter and quantity of humic substances, i.e., a sample with a high content of organic matter cannot have a high content of humic substances. This fact may be demonstrated by evaluating Table 2, which indicates that soils with minor amounts of organic matter have high contents of humic substances. Moreover, still evaluating Table 2, we find a relation between humic substances and adsorption of glyphosate: the higher the content of humic substances greater the adsorption of glyphosate in the samples.

Table 2. Percentage of humic substances (in increasing order) and adsorption in the evaluated soil samples

\begin{tabular}{lll}
\hline Sample & $\mathrm{g}(\mathrm{HS}) /(100 \mathrm{~g}$ sample $)$ crescent order & Adsorption $\left(\mu \mathrm{g} \mathrm{g}^{-1}\right) \times 10^{-2}$ \\
\hline Soil G & $0.059(0.003)$ & $14(2)$ \\
Soil E & $0.197(0.010)$ & $48(3)$ \\
Soil C & $0.422(0.020)$ & $98(5)$ \\
Soil F & $0.910(0.046)$ & $237(12)$ \\
Soil B & $1.244(0.062)$ & $297(15)$ \\
Soil D & $2.444(0.122)$ & $361(18)$ \\
Soil A & $3.249(0.162)$ & $416(21)$ \\
\hline
\end{tabular}

The interaction of glyphosate with the soil constituents occurs manly via $\mathrm{H}$ bonds with humic substances, preferably due to the greater surface area of contact (Piccolo, 1996) and via the N-quaternary. Adsorption may also occur via interaction with the ions Fe (III) and Al (III) present in the structure of the humic substances. This type of adsorption can be attributed to a ligand exchange in which one or more hydroxyls of the hydration sphere of the metal ion can be replaced by existing phosphonic acid group due to the acid medium (Albers et al., 2009).

After 12 hours (data not shown) an equilibrium was established between glyphosate adsorbed fraction and the free fraction, which follows the following reaction: 


$$
G l y_{(\text {free })} \underset{K_{D}}{\stackrel{K_{A}}{\rightleftharpoons}} G l y_{(a d s)}
$$

Thus, we can calculate an equilibrium constant for the reaction (adsorption constant):

$$
K_{A}=\frac{\left[G y_{(a d s)}\right]}{\left[G y_{(\text {free })}\right]}
$$

Figure 4 shows the association constant $\left(K_{A}\right)$ and dissociation constant $\left(K_{D}\right)$ on a logarithmic scale as a function of the mass of humic substances. Figure 5 shows the same data now normalized for better viewing.

Analyzing the Figures 4 and 5, it can be concluded that from about 1.5 of humic fraction mass, the interaction sites are saturated, thus an increase in the humic fraction content does not lead to an increase in adsorption. This fact can be explained by changes in compaction that humic substances may suffer when their amount increases (Piccolo et al., 1996), which leads to a decrease in surface contact area, hindering the interaction mechanism via $\mathrm{H}$ bonds, interactions with $\mathrm{N}$-quaternary or $\mathrm{Fe}$ (III) and $\mathrm{Al}$ (III) ions present in the structure of the humic substances as discussed above.

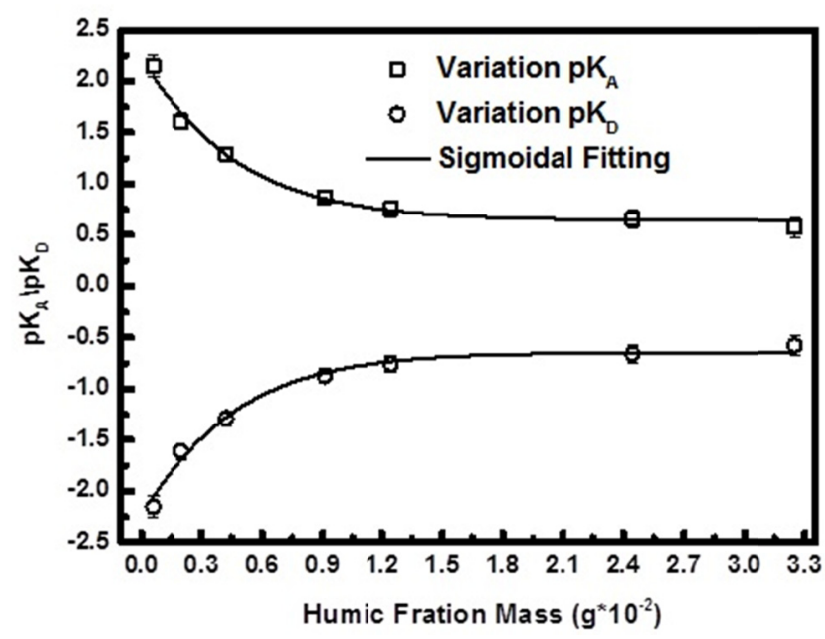

Figure 4. The association constant $\left(\mathrm{K}_{\mathrm{A}}\right)$ and dissociation constant $\left(\mathrm{K}_{\mathrm{D}}\right)$ on a logarithmic scale as a function of the mass of humic substances

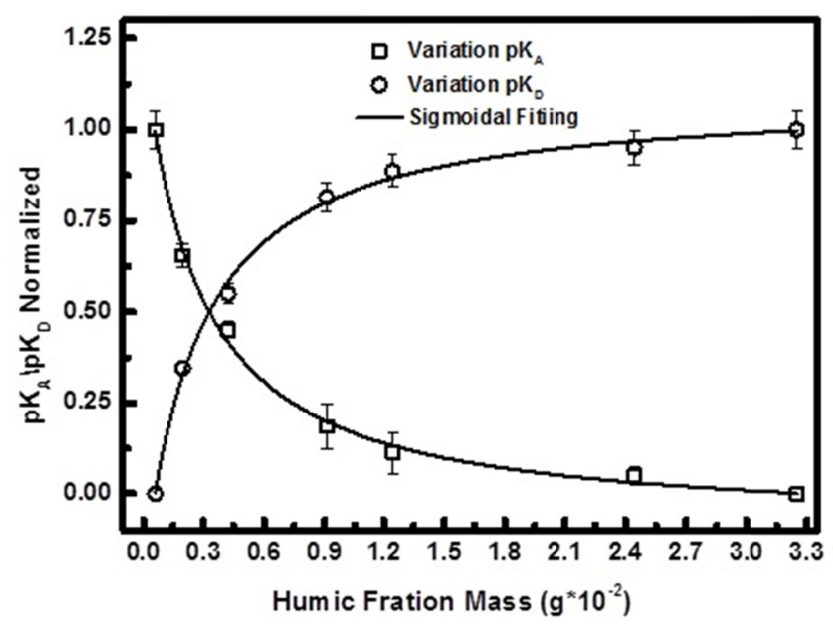

Figure 5. The normalized data of the Table 4 results 
It is known that the clays have great importance in soil adsorptive processes; however, for the evaluated soil samples the role of clays seems not to be as significant as the humic substances.

Low adsorption on soils due to clays can be related to the type of clay and the presence of cations with smaller ionic radius size. It is well reported that the adsorption of glyphosate in clays increases in saturated clays with cations of $\mathrm{Al}$ (III), Fe (III) and Fe (II). A deficiency of these structures can lead to decrease in soil ability to adsorb glyphosate (Zhao et al., 2015).

It is fair to observe that glyphosate adsorption is related not only to the quantity of clay in the soil, but also to the active sites of the humic acids present in soil organic matter. In addition, it is worth to mention that the O.M. content is not directly related to the HS content, and more: the desorption of glyphosate is not slightly related to the HS content, but there is a compromise between the quantity of HS and their superficial area available to interaction.

\section{Conclusions}

Humic substances have an important role in the mobility of the glyphosate in the evaluated soil samples, due to the great adsorption of the analyte into soils. Moreover, the data suggest that an increase in the humic substances leads to an increase in the adsorption process up to a certain point. This point is reached under a decrease in the surface area, which in turn is reached at high concentration of salts and/or humic substances themselves, unveil the statement that adsorption is straight related to high quantities of humic substances.

These data allow us to hypothesize the interaction mechanism between glyphosate and humic substances in slightly acid medium, such as tropical soils.

\section{Acknowlegements}

M. O. O. Rezende thanks to FAPESP and CNPq fellowship (process number 2008/54686-2 and 306715/2013-9, respectively). F. Benetti thanks to FAPESP for grant (process number 2011/22651-8).

\section{References}

ABNT (Associação Brasileira de Normas Técnicas). (1984). NBR 7181-Solo-Análise Granulométrica.

ABNT (Associação Brasileira de Normas Técnicas). (1986). NBR 6457-Amostras de solo-preparaçao para ensaios de compactaçao e ensaios de caracterização.

Albers, C. N., Banta, G. T., Hansen, P. E., \& Jacobsen, O. S. (2009). The influence of organic matter on sorption and fate of glyphosate in soil - Comparing different soils and humic substances. Environmental Pollution, 157, 2865-70. http://dx.doi.org/10.1016/j.envpol.2009.04.004

Annett, R., Habibi, H. R., \& Hontela, A. (2014). Impact of glyphosate and glyphosate-based herbicides on the freshwater environment. Journal of Applied Toxicology, 34, 458-479. http://dx.doi.org/10.1002/jat.2997

AOAC (Association of Official Analytical Chemists). (2002). Appendix D : Guidelines for Collaborative Study Procedures To Validate Characteristics of a Method of Analysis. AOAC Official.

Beckie, H. J. (2011). Herbicide-resistant weed management: focus on glyphosate. Pest Management Science, 67, 1037-1048. http://dx.doi.org/10.1002/ps.2195

Duke, S. O., \& Powles, S. B. (2008). Glyphosate: a once-in-a-century herbicide. Pest Management Science, 64, 319-325. http://dx.doi.org/10.1002/ps.1518

Ghafoor, A., Jarvis, N. J., \& Stenström, J. (2013). Modelling pesticide sorption in the surface and subsurface soils of an agricultural catchment. Pest Management Science, 69, 919-929. http://dx.doi.org/ $10.1002 /$ ps.3453

Green, J. M. (2014). Current state of herbicides in herbicide-resistant crops. Pest Management Science, 70, 1351-1357. http://dx.doi.org/10.1002/ps.3727

Jodeh, S., Attallah, M., Haddad, M., Hadda, T. B., Salghi, R., Jodeh, D., \& Warad, I. (2014). Fate and Mobility of Glyphosate Leachate in Palestinian Soil Using Soil Column. Journal of Materials and Environmental Sciences, 5, 2008-2016.

Kraehmer, H., Laber, B., Rosinger, C., \& Schulz, A. (2014). Herbicides as weed control agents - state of the art. I. Weed control research and safener technology: The path to modern agriculture. Plant Physiology, 166, 1119-1131. http://dx.doi.org/10.1104/pp.114.241901

Kylin, H. (2013). Time-integrated sampling of glyphosate in natural waters. Chemosphere, 90, 1821-1828. http://dx.doi.org/10.1016/j, chemosphere.2012.09.020 
Moraes, S. L., \& Rezende, M. O. O. (2004). Determinação da concentração micelar crítica de ácidos húmicos por medidas de condutividade e espectroscopia. Quimica Nova, 27, 701-705. http://dx.doi.org/10.1590/ S0100-40422004000500004

Piccolo, A., Celano, G., \& Conte, P. (1996). Adsorption of Glyphosate by Humic Substances. Journal of Agricultural and Food Chemistry, 44, 2442-2446. http://dx.doi.org/10.1021/j9950620x

Rubin, J. L., Gaines, C. G., \& Jensen, R. A. (1984). Glyphosate Inhibition of 5-Enolpyruvylshikimate 3-Phosphate Synthase from Suspension-Cultured Cells of Nicotiana silvestres. Plant Physiol., 75, 839-845. http://dx.doi.org/10.1104/pp.75.3.839

Silva, B. M., Benetti, F., Rezende, M. O. O. (2015). Comparative Study of Glyphosate and AMPA Determination in Environmental Samples by Two Green Methods (Vol. 2, pp. 1-11). Open Access Library, Scientific Research Publishing. http://dx.doi.org/10.4236/oalib.1101553

Sparks, D. L., Page, A. L., Helmke, P. A., Loeppert, R. H., Soltanpour, P. N., Tabatabai, M. A., ... Sumner, M. E. (1996). Methods of Soil Analysis - Part 3: Chemical Methods, Methods of Soil Analysis (p. 1264). Madison, Wisconsin, USA: Soil Science Society of America: American Society of Agronomy.

Toni, L. R. M., Santana, H. S., \& Zaia, A. M. (2006). Adsorção de glifosato sobre solos e minerais. Quimica Nova, 29, 829-833. http://dx.doi.org/10.1590/S0100-40422006000400034

Tonini, R. M. C. W., Rezende, C. E., \& Gravitol, A. D. (2010). Degradação e biorremediação de compostos do petróleo por bactérias: Revisão. Oecologia Australis, 14, 1021-1035. http://dx.doi.org/10.4257/ oeco.2010.1404.11

Trevisan, S., Francioso, O., Quaggiotti, S., \& Nardi, S. (2010). Humic substances biological activity at the plant-soil interface: from environmental aspects to molecular factors. Plant Signaling \& Behavior, 5, 635-643. http://dx.doi.org/10.4161/psb.5.6.11211

Wang, Y., Li, Y., Ye, X., Chu, Y., \& Wang, X. (2010). Profile storage of organic/inorganic carbon in soil: From forest to desert. Science of the Total Environment, 408, 1925-1931. http://dx.doi.org/10.1016/ j.scitotenv.2010.01.015

Zhao, Y., Wendling, L. A., Wang, C., \& Pei, Y. (2015). Use of Fe/Al drinking water treatment residuals as amendments for enhancing the retention capacity of glyphosate in agricultural soils. Journal of Environmental Sciences, 34, 133-142. http://dx.doi.org/10.1016/j.jes.2015.01.030

\section{Copyrights}

Copyright for this article is retained by the author(s), with first publication rights granted to the journal.

This is an open-access article distributed under the terms and conditions of the Creative Commons Attribution license (http://creativecommons.org/licenses/by/4.0/). 